\title{
Pemanfaatan Dana PKH oleh Masyarakat Kurang Mampu di Kanagarian Alahan Panjang
}

\author{
Mai Parni, Nurman S \\ Program Studi Pendidikan Pancasila dan Kewarganegaraan \\ Universitas Negeri Padang \\ E-mail: mai.parni28@gmail.com
}

\section{ABSTRAK}

Kemiskinan masih menjadi permasalahan utama di negara berkembang termasuk Indonesia. Pemerintah telah melakukan berbagai macam program pengentasan kemiskinan untuk mengurangi angka kemiskinan, salah satunya yaitu Program Keluarga Harapan (PKH). Artikel ini bertujuan mendeskripsikan pemanfaatan dana PKH oleh masyarakat kurang mampu dalam bidang pendidikan dan kesehatan di Alahan Panjang beserta dengan permasalahan yang terjadi dalam proses pemanfaatan dana dan penyebab terjadinya permasalahan dalam pemanfaatan dana PKH di nagari tersebut. Penelitian ini dilakukan di Kanagarian Alahan Panjang, Kecamatan Lembah Gumanti, Kabupaten Solok. Metode penelitian dilakukan melalui pendekatan kualitatif deskriptif dengan menggunakan data primer dan sekunder. Informan penelitian adalah dinas sosial, pendamping PKH, dan penerima PKH. Teknik pengumpulan data pada penelitian ini menggunakan wawancara, observasi dan studi dokumentasi. Uji keabsahan data menggunakan teknik triangulasi data. Teknik analisis data melalui tiga alur kegiatan yaitu reduksi data, penyajian data dan penarikan kesimpulan. Hasil penelitian menunjukkan bahwa dalam proses pemanfaatan dana PKH masyarakat penerima menggunakannya untuk keperluan pendidikan dan kesehatan. Namun, masih terjadi permasalahan yaitu adanya penerima PKH yang kurang cermat dalam mengelola dana dan memanfaatkan dana tidak untuk pendidikan dan kesehatan. Hal tersebut terjadi karena kurangnya pengawasan pendamping, penerima tidak hadir saat sosialisasi, dan dana tidak tepat sasaran.

Kata Kunci: pemanfaatan dana PKH, masyarakat kurang mampu, Alahan Panjang

\section{ABSTRACT}

Poverty is still a major problem in developing countries, including Indonesia. The government has carried out various poverty alleviation programs to reduce poverty, one of which is the Family Hope Program (PKH). This article aims to describe the utilization of PKH funds by disadvantaged people in the field of education and health in Alahan Panjang along with the problems that occur in the process of utilizing funds and the causes of problems in the utilization of PKH funds in the nagari. This research was conducted in Kanagarian Alahan Panjang, Lembah Gumanti District, Solok Regency. The research method is done through a descriptive qualitative approach using primary and secondary data. Research informants were social services, PKH assistants, and PKH recipients. Data collection techniques in this study used interviews, observation and documentation studies. Data 
validity test uses data triangulation techniques. Data analysis techniques through three activities, namely data reduction, data presentation and drawing conclusions. The results showed that in the process of utilizing PKH funds the recipient community used them for education and health purposes. However, there are still problems, namely the existence of $P K H$ recipients who are less careful in managing funds and use funds not for education and health. This happened because of the lack of companion supervision, the recipient was not present during the socialization, and the funds were not on target.

Keywords : utilization of PKH, poor people, Alahan Panjang

\section{PENDAHULUAN}

Kemiskinan masih menjadi salah satu permasalahan utama di negara berkembang termasuk Indonesia. Pengentasan kemiskinan sudah dilakukan oleh pemerintah bersama masyarakat melalui berbagai program. Program-program tersebut mencakup upaya-upaya baik melalui penyediaan kebutuhan pangan, layanan kesehatan dan pendidikan, pemberian dana bantuan, pembangunan sarana prasarana, dll. Terdapat banyak program yang dicanangkan diantaranya Program Keluarga Harapan yang disingkat PKH sejak tahun 2007 dan berfokus pada 2 komponen yaitu bidang kesehatan dan pendidikan. Agar tercapainya tujuan program tersebut maka perlu diketahui bagaimana pemanfaatan dana PKH oleh masyarakat kurang mampu karena hal tersebut sangat berkaitan dengan pengentasan kemiskinan di Indonesia.

Penelitian tentang $\mathrm{PKH}$ telah banyak dilakukan oleh beberapa peneliti terdahulu. Dalam penelitian yang dilakukan oleh Dheby (2017) menyatakan bahwa bagi masyarakat miskin pelayanan kesehatan yang belum memuaskan dan mahalnya biaya pendidikan dirasa sangat menyulitkan mereka. Masalah ini bisa diatasi melalui pelaksanaan $\mathrm{PKH}$. Pernyataan tersebut juga sesuai dengan penelitian yang dilakukan oleh Indriani (2017) yang menyatakan bahwa pemanfaatan PKH mampu memberikan kontribusi yang serius dalam membantu keluarga miskin karena menekankan langsung pada subjeknya. Menurut Lidiana (2014) rendahnya penghasilan keluarga sangat miskin membuat mereka tidak mampu memenuhi kebutuhan pendidikan bahkan untuk tingkat minimal sekalipun. Sehingga, dana PKH diberikan untuk meningkatkan partisipasi pendidikan anak-anak keluarga penerima.

Dalam penelitiannya Adisanjaya (2016) menyatakan bahwa jumlah penduduk Indonesia yang tergolong miskin cukup tinggi, belum lagi yang tergolong rentan miskin. Untuk mengatasi hal tersebut menurut Ekardo (2014), pemerintah Indonesia melakukan berbagai upaya untuk menanggulangi kemiskinan salah satunya melalui PKH. Rusydi (2016) dalam penelitiannya juga menyatakan bahwa bantuan PKH mempengaruhi partisipasi pendidikan anak-anak keluarga miskin dan pengaruh itu 
sangat sigifikan. Dalam penelitian Utomo (2014) juga menyatakan bahwa PKH bertujuan untuk memberikan bukti nyata dalam tujuan meningkatkan kualitas hidup masyarakat miskin. Hal tersebut memperlihatkan bahwa sejauh ini PKH memang sudah menjadi program yang berpengaruh dalam pengentasan kemiskinan. Hal tersebut juga sesuai dengan penelitian yang dilakukan oleh Virgoreta (2015) yang menyatakan bahwa implementasi PKH yang baik akan mengurangi tingginya jumlah rumah tangga miskin.

Dalam beberapa penelitian yang telah dilakukan oleh peneliti sebelumnya, banyak yang membahas mengenai implementasi dan pelaksanaan $\mathrm{PKH}$ dalam meningkatkan kualitas hidup masyarakat miskin, analisis pemanfaatan $\mathrm{PKH}$, dan pengaruh $\mathrm{PKH}$ terhadap partisipasi pendidikan.

Namun, belum ada yang meneliti bagaimana pemanfaatan dana bantuan PKH oleh masyarakat kurang mampu. Jumlah masyarakat kurang mampu di Indonesia yang menerima bantuan $\mathrm{PKH}$ meningkat setiap tahunnya yaitu pada tahun 2015 sebanyak 3,5 juta jiwa, tahun 2016 sebanyak 6 juta jiwa, tahun 2017 sebanyak 6,2 juta jiwa, tahun 2018 sebanyak 10 juta jiwa dan tahun 2019 sebanyak 10 juta jiwa. Penerima PKH di Kabupaten Solok sebanyak 38.586 jiwa, penerima $\mathrm{PKH}$ di Kanagarian Alahan Panjang sebanyak 936 jiwa dengan perincian sebagai berikut:

Tabel 1

Jumlah penerima PKH di Kanagarian Alahan Panjang
Volume 1 No. 42018

\begin{tabular}{|c|l|l|}
\hline No. & \multicolumn{1}{|c|}{ Komponen } & Jumlah \\
\hline 1 & Ibu Hamil & 3 \\
\hline 2 & Balita & 104 \\
\hline 3 & Anak Pra Sekolah & 45 \\
\hline 4 & Anak SD & 436 \\
\hline 5 & Anak SMP & 197 \\
\hline 6 & Anak SMA & 119 \\
\hline 7 & Lansia & 24 \\
\hline 8 & Disabilitas & 8 \\
\hline
\end{tabular}

Sumber : sekretariat PKH Kabupaten Solok Jumlah dana bantuan yang diberikan dalam PKH per keluarga berbeda-beda tergantung kepada jumlah komponen dalam keluarga yang bisa menerima dana tersebut. Jumlah dana yang diberikan sesuai komponen sebagai berikut:

\section{Tabel 2}

Jumlah dana PKH yang diterima tiap komponen dalam keluarga

\begin{tabular}{|c|l|l|}
\hline No. & \multicolumn{1}{|c|}{ Komponen } & \multicolumn{1}{c|}{ Jumlah dana } \\
\hline 1 & Ibu Hamil & Rp 2.400 .000 \\
\hline 2 & Balita & Rp 2.400 .000 \\
\hline 3 & Anak Pra Sekolah & Rp 2.400 .000 \\
\hline 4 & Anak SD & Rp 900.000 \\
\hline 5 & Anak SMP & Rp 1.500 .000 \\
\hline 6 & Anak SMA & Rp 2.000 .000 \\
\hline 7 & Lansia & Rp 2.400 .000 \\
\hline 8 & Disabilitas & Rp 2.400 .000 \\
\hline
\end{tabular}

Sumber : sekretariat PKH Kabupaten Solok

Namun, terdapat masalah pemanfaatan dana bantuan PKH yaitu masyarakat penerima kurang cermat dalam mengelola dana bantuan dan menggunakan dana tidak untuk kesehatan dan pendidikan. Mereka membeli barang elektronik, membeli rokok, membayar hutang, merenovasi rumah, dan membeli bibit tanaman. Hal tersebut tentu tidak sesuai dengan tujuan dimana PKH diharapkan mampu meningkatkan kesejahteraan masyarakat penerima dana tersebut. Oleh sebab itu penelitian tentang pemanfaatan dana bantuan $\mathrm{PKH}$ oleh masyarakat kurang mampu perlu dilakukan karena sangat berkaitan dengan tingkat kesejahteraan 
masyarakat penerima dan bagaimana masyarakat memanfaatkan dana tersebut untuk memenuhi kebutuhan mereka terutama dalam hal kesehatan dan pendidikan.

Oleh karena itu yang menjadi tujuan dalam artikel ini adalah mendeskripsikan bagaimana pemanfaatan dana PKH oleh masyarakat kurang mampu dalam bidang pendidikan dan kesehatan di Kanagarian Alahan Panjang dan mendeskripsikan permasalahan apa saja yang terjadi dan faktor-faktor yang mempengaruhi pemanfaatan dana tersebut. Sehingga diharapkan artikel ini bermanfaat untuk mengembangkan kemampuan peneliti dalam bidang ilmiah dan menambah pengetahuan tentang bagaimana pemanfaatan dana PKH bagi kesejahteraan masyarakat kurang mampu di Kanagarian Alahan Panjang, serta untuk dijadikan pedoman bagi penelitian selanjutnya.

\section{METODE PENELITIAN}

Jenis penelitian ini adalah penelitian kualitatif deskriptif karena penelitian ini akan mendeskripsikan bagaimana pemanfaatan dana $\mathrm{PKH}$ oleh masyarakat penerima di Kanagarian Alahan Panjang. Penelitian mengenai pemanfaatan PKH oleh masyarakat kurang mampu ini akan dilakukan di Kanagarian Alahan Panjang, Kecamatan Lembah Gumanti, Kabupaten Solok. Informan dalam penelitian ini ditentukan dengan menggunakan teknik purposive sampling. Informan dalam penelitian ini yaitu dinas sosial Kabupaten Solok, pendamping $\mathrm{PKH}$, dan penerima PKH. Teknik pengumpulan data pada penelitian ini menggunakan wawancara, observasi dan studi dokumentasi. Uji keabsahan data menggunakan teknik triangulasi data. Teknik analisis data melalui tiga alur kegiatan yaitu reduksi data, penyajian data dan penarikan kesimpulan.

\section{HASIL DAN PEMBAHASAN}

Menurut Abdulsyani (2012:190) kemiskinan adalah suatu keadaan dimana seseorang, keluarga atau anggota masyarakat tidak mempunyai kemampuan untuk memenuhi kebutuhan hidupnya secara wajar sebagaimana anggota masyarakat lain pada umumnya. Pada umumnya masyarakat miskin sulit memenuhi tiga kebutuhan pokok yaitu kesempatan untuk memperoleh pendidikan, kesehatan, dan ketersediaan air. Oleh sebab itu, pemerintah melaksanakan program pengentasan kemiskinan. $\mathrm{PKH}$ merupakan program pemberian bantuan sosial bersyarat kepada keluarga miskin yang disebut dengan Keluarga Penerima Manfaat PKH.

PKH berfokus pada dua komponen yaitu bidang kesehatan dan pendidikan. Tingkat pendapatan keluarga miskin sangat dipengaruhi oleh kedua bidang tersebut. Rendahnya tingkat pendidikan akan memiliki resiko pengangguran dan kemiskinan. Begitu juga dengan kesehatan dimana kesehatan yang tidak terjamin juga menyebabkan keluarga miskin kesulitan memenuhi kebutuhan hidupnya. Masyarakat miskin sulit memenuhi tiga kebutuhan pokok yaitunya kesempatan untuk memperoleh pendidikan, kesehatan, dan ketersediaan air. Oleh sebab itu dengan adanya PKH diharapkan keluarga penerima mampu meningkatkan kesejahteraan hidupnya. 


\section{Bidang Pendidikan}

Menurut Rusydi (2016), masih adanya anak usia sekolah yang tidak melanjutkan sekolah dengan berbagai alasan karena mau bekerja mencari nafkah, tidak ada biaya, dan merasa pendidikannya sudah cukup maka PKH menjadi program pengembangan perlindungan sosial. Dalam bidang pendidikan keluarga peserta $\mathrm{PKH}$ memiliki kewajiban untuk mendaftarkan anggota keluarganya pada tingkat Pendidikan dasar dan menengah ke satuan pendidikan formal.

Berdasarkan data yang ada di Kanagarian Alahan Panjang terdapat komponen PKH bidang pendidikan yang bersekolah di SD sebanyak 436 orang, SMP sebanyak 197 orang dan SMA sebanyak 119 orang. Keluarga penerima memanfaatkan dana untuk membiayai pendidikan anaknya yaitu membeli seragam sekolah, membeli perlengkapan sekolah, biaya sekolah, dan tabungan. Namun, hal tersebut belum dilakukan oleh setiap keluarga penerima. Ada yang beralasan dana bisa digunakan untuk memenuhi keperluan lain seperti untuk bertani dan beranggapan panen hasil bertani bisa digunakan untuk biaya sekolah anak selanjutnya. Padahal hal tersebut dikhawatirkan belum bisa menjamin pendidikan anak.

2. Bidang Kesehatan

Menurut Dheby

(2017),

kesehatan merupakan salah satu kunci untuk melakukan berbagai aktifitas termasuk pendidikan yang secara langsung akan meningkatkan kualitas sumber daya manusia. Di Kanagarian Alahan Panjang dalam bidang kesehatan terdapat komponen $\mathrm{PKH}$ ibu hamil 3 orang, balita 104 orang, lansia 24 orang, dan disabilitas 8 orang.
Dalam bidang kesehatan keluarga peserta PKH memiliki kewajiban untuk memeriksa kesehatannya ke rumah sakit atau puskesmas untuk mendapatkan layanan kesehatan sesuai kebutuhannya. Dana yang didapatkan oleh keluarga penerima PKH dimanfaatkan untuk membiayai layanan kesehatan. Demi kelancaran PKH, dinas sosial bekerja sama dengan dinas kesehatan untuk menyediakan fasilitas dan pelayanan kesehatan yang baik bagi penerima PKH yang pergi ke rumah sakit atau puskesmas.

Dalam bidang kesehatan, dana yang didapatkan oleh keluarga penerima PKH dimanfaatkan untuk membiayai layanan kesehatan yaitu bagi ibu hamil diwajibkan untuk memeriksa kandungan dan membeli asupan gizi kesehatan selama masa kehamilan dan melahirkan karena hal tersebut sangat menentukan kelangsungan hidup ibu dan bayi. Bagi keluarga penerima yang memiliki balita maka dana PKH digunakan untuk membeli perlengkapan bayi, membeli susu, imunisasi, dan membeli vitamin untuk pertumbuhan yang baik bagi bayi tersebut. Dana PKH yang diberikan kepada lansia dimanfaatkan untuk memeriksa kesehatan ke puskesmas atau rumah sakit, membeli obat jika memiliki riwayat penyakit tertentu. Bagi keluarga yang memiliki anggota keluarga yang disabilitas maka harus digunakan untuk meningkatkan kesejahteraannya.

Namun, belum semua keluarga penerima memanfaatkan dana untuk kesehatan. Masih ada yang menggunakan untuk membeli barang dagangan dan merenovasi rumah, padahal anggota keluarganya ada yang sakit dan masih balita. Sesuai ketentuan yang seharusnya keluarga 
penerima harus melaksanakan kewajiban mereka terutama jika dalam keluarga ada yang membutuhkan layanan kesehatan.

Permasalahan dalam Pemanfaatan Dana PKH

Menurut Nurmasyitah (2017), mengentaskan kemiskinan bukanlah hal yang sederhana, tetapi harus dilakukan dengan perencanaan yang terintegrasi dan terkoordinir dengan baik melalui berbagai macam kebijakan dan program yang berkelanjutan. Dalam pelaksanaan sebuah kebijakan pasti ada sebuah permasalahan yang terjadi, begitu juga dalam kebijakan pengentasan kemiskinan. Salah satu permasalahan yang terjadi dalam PKH adalah masalah pemanfaatannya yang tidak sesuai dengan yang seharusnya. Dalam Peraturan Menteri Sosial Republik Indonesia Nomor 1 tahun 2018, PKH merupakan pengembangan dari sistem perlindungan sosial yang meringankan dan membantu keluarga miskin dalam akses kesehatan dan pendidikan sehingga dana yang diberikan harus digunakan untuk pendidikan dan kesehatan.

Di Kanagarian Alahan Panjang terlihat masih adanya keluarga penerima dana $\mathrm{PKH}$ yang kurang cermat dalam mengelola atau memanfaatkan dana bantuan tersebut. Mereka memanfaatkan dana PKH tidak untuk pendidikan dan kesehatan. Ada keluarga penerima yang menghabiskan dana PKH untuk membeli keperluan lain seperti membeli barang elektronik, membeli rokok, membayar cicilan, dan merenovasi rumah. Hal tersebut tentu saja tidak sesuai dengan tujuan awal PKH untuk meningkatkan kesejahteraan masyarakat penerima terutama di bidang pendidikan dan kesehatan.

\section{Faktor-faktor yang mempengaruhi pemanfaatan dana PKH}

Ada beberapa faktor yang mempengaruhi pemanfaatan dana PKH oleh penerima. Faktor yang pertama yaitu kurangnya pengawasan dari pendamping PKH. Pendamping $\mathrm{PKH}$ adalah orang yang sangat penting dalam kelancaran pelaksanaan PKH karena pendamping berhubungan langsung dengan penerima PKH. Salah satu tugas dari pendamping $\mathrm{PKH}$ adalah memberikan informasi kepada penerima PKH. Informasi juga bisa diberikan kepada ketua kelompok dan ketua kelompok akan memberitahukan kepada anggota kelompok. Ketua kelompok membantu pendamping untuk mendatangi rumah penerima $\mathrm{PKH}$ untuk memberitahukan dan mengajak penerima PKH untuk hadir jika ada pertemuan. Dalam pemberian informasi terkait $\mathrm{PKH}$ pelaksanaanya kurang efektif karena hanya beredar dari pemberitahuan bergilir sesama anggota. Jumlah pendamping $\mathrm{PKH}$ untuk Kecamatan Lembah Gumanti ada 10 orang dan setiap pendamping mendampingi 230-250 penerima. Jumlah pendampingan yang cukup besar mengakibatkan pendamping sedikit kesulitan dalam mengawasi keluarga penerima terutama terkait bagaimana mereka memanfaatkan dana tersebut.

\begin{tabular}{lccc}
\multicolumn{1}{c}{ Faktor } & \multicolumn{2}{c}{ kedua } & yang \\
mempengaruhi & pemanfaatan dana \\
PKH adalah & Penerima & PKH & tidak \\
menghadiri & kegiatan & sosialisasi. \\
Kegiatan sosialisasi & PKH & yang \\
dilakukan & adalah & Pertemuan \\
Peningkatan & Kemampuan & Keluarga
\end{tabular}


(P2K2). Kegiatan ini seharusnya diberikan empat kali dalam sebulan. Sosialisasi harus diberikan karena sangat menentukan kesuksesan pelaksanaan PKH. Sosialisasi diberikan untuk memberitahukan kapan dana bantuan keluar dan untuk hal apa saja dana tersebut harus digunakan. Materi sosialisasi juga berisi mekanisme pelaksanaan $\mathrm{PKH}$ dan berbagai kebijakan terkait PKH. Di Kanagarian Alahan Panjang dalam kegiatan pertemuan anggota $\mathrm{PKH}$ dengan pendamping $\mathrm{PKH}$ yang telah dilakukan masih ada penerima yang tidak hadir dengan berbagai alasan. Hal tersebut menunjukan bahwa penerima yang tidak hadir tidak akan paham dengan informasi dan berbagai ketentuan PKH.

Faktor ketiga yang mempengaruhi pemanfaatan dana PKH adalah penerima yang tidak tepat sasaran. Pelaksanaan PKH dilakukan dengan beberapa tahapan. Terdapat tahap penetapan calon penerima $\mathrm{PKH}$ dan penetapan keluarga penerima manfaat PKH. Penerima PKH rata-rata adalah keluarga yang pernah menerima subsidi BBM, sehingga belum semua keluarga miskin terdaftar sebagai penerima PKH. Di Alahan Panjang masih terdapat keluarga penerima yang memiliki rumah permanen dan komponen yang sudah meninggal dunia.

\section{KESIMPULAN}

PKH merupakan salah satu program pemerintah dalam mengentaskan kemiskinan yang dicanangkan sejak tahun 2007 dan berfokus pada dua bidang yaitu bidang pendidikan dan bidang kesehatan. Dalam bidang pendidikan, dana yang didapatkan oleh keluarga penerima $\mathrm{PKH}$ dimanfaatkan untuk membiayai pendidikan anak seperti membeli seragam sekolah, membeli perlengkapan sekolah, biaya sekolah, dan tabungan sekolah. Dalam bidang kesehatan, dana yang didapatkan oleh keluarga penerima PKH dimanfaatkan untuk membiayai layanan kesehatan yaitu Posyandu bagi ibu hamil dan balita, membeli perlengkapan bayi, membeli susu, imunisasi, dan membeli vitamin. Bagi lansia dana digunakan untuk memeriksa kesehatan ke puskesmas atau rumah sakit dan membeli obat. Sementara bagi disabilitas, dana digunakan untuk meningkatkan kesejahteraannya.

Salah satu permasalahan yang terjadi dalam PKH adalah masalah pemanfaatannya yang tidak sesuai dengan yang seharusnya. Masih adanya keluarga penerima dana $\mathrm{PKH}$ yang kurang cermat dalam mengelola atau memanfaatkan dana bantuan tersebut. Faktor-faktor yang mempengaruhi pemanfaatan dana PKH yaitunya kurangnya pengawasan dari pendamping $\mathrm{PKH}$, penerima $\mathrm{PKH}$ tidak menghadiri kegiatan sosialisasi $\mathrm{PKH}$, dan adanya penerima PKH yang tidak tepat sasaran.

\section{DAFTAR PUSTAKA}

Abdulsyani. 2012. Sosiologi: Skematika, Teori, dan Terapan. Jakarta: Bumi Aksara

Dheby, Clara. dkk. 2017. "Implementasi PKH di Kec.Tamalate, Kota Makassar". Jurnal Administrasi Publik. Vol.3, No.2, Tahun 2017

Ekardo, Apando. dkk. 2014. “Efektifitas PKH dalam Upaya Pengentasan Kemiskinan di Nagari Lagan Hilir, Kab.Pesisir Selatan". Jurnal Ilmu Sosial 
Mamangan. Vol. III, No.1, Januari-Juni 2014

Indriani, Kadek Dina. 2017. “Analisis pemanfaatan PKH Terhadap Peningkatan Kesejahteraan Masyarakat Miskin di Kec. Buleleng tahun 2011-2015". Jurnal Jurusan Pendidikan Ekonomi. Vol.10, No.2, Tahun 2017

Lidiana, dkk. 2014. "Pengaruh dan Efektifitas Bantuan PKH Terhadap Partisipasi Pendidikan di Kec.Muara Tiga, Kab.Pidie".Jurnal Ilmu Ekonomi.Vol. 2 No. 2 Mei 2014

Nurmasyitah. dkk. 2017."Upaya Pemerintah dalam Menanggulangi Kemiskinan". Jurnal Pesona Dasar. Vol.1, No.5, April 2017

Peraturan Menteri Sosial Republik Indonesia Nomor 1 tahun 2018 tentang $\mathrm{PKH}$

Rusydi. 2016. "Pengaruh PKH terhadap Partisipasi Pendidikan di Kec. Indrajaya, Kab. Pidie". Jurnal Manajemen Ekonomi dan Bisnis.Vol.17, No.1, April 2016

Suleman dan Resnawaty. 2016. "PKH antara Perlindungan Sosial dan Pengentasan Kemiskinan". Vol.4, No.1, ISSN 2442-4480

Utomo, Dedy. dkk. 2014. "Pelaksanaan PKH dalam Meningkatkan Kualitas Hidup Rumah Tangga Miskin (Studi pada Unit Pelaksanaan PKH Kec. Purwoasri, Kab. Kediri)".Jurnal Administrasi Publik. Vol.2, No.1 